\title{
Adpositions in Media Lengua: Quichua or Spanish? - Evidence of a Lexical-Functional Split
}

\author{
Isabel Deibel \\ Pennsylvania State University \\ ideibel@psu.edu
}

\begin{abstract}
After decades of debate in linguistic theory, the lexical/functional status of adpositions is still controversial. Lexicon-Grammar mixed languages such as Media Lengua, spoken in Northern Ecuador, are excellent testing cases for such grammatical categories: This mixed language displays a conservative Quichua morphosyntactic frame while approximately $90 \%$ of its lexical roots are relexified from Spanish. Thus, due to the lexical-functional split Media Lengua displays, whether adpositions in this language are realized in Quichua or Spanish can speak to their status as a lexical/functional category. This study reports data from recent field research, conducted with speakers trilingual in Media Lengua, Quichua and Spanish who participated in two tasks (video description and translation). The results show a split between lexical and functional adpositions in Media Lengua, manifested in the dual-language realization of complex (multimorphemic) items: The lexical part of these complex items is relexified from Spanish while the functional part is retained in Quichua - even when participants are structurally primed. This suggests that Media Lengua across communities systematically follows Quichua morphosyntactic rules.
\end{abstract}

\section{Keywords}

adpositions - Media Lengua - mixed language - lexical-functional debate - Imbabura Quichua - Spanish 


\section{Introduction}

Little consensus exists on the nature of adpositions in the world's languages. In view of their elusive linguistic behavior, some have suggested that they straddle the boundary between lexicon and grammar (e.g. Abney, 1987; Hagège, 2010) and are a hybrid category (Rauh, 1991; Zwarts, 1997); other areas of linguistics still treat them as unified (e.g. Chan, 2008).

Research examining adpositions in language contact situations is scarce. As some researchers have noted that previous approaches to adpositions only hold true for a "selected subset" instead of the "set of [ad]positions as a whole" (Rauh, 1991:175), analyses focussing on contact languages may reveal the underlying mechanisms that govern these structures and prove relevant what other authors have considered to be superfluous distinctions. In an attempt to address this dearth of literature, this paper analyzes the morphosyntactic nature of adpositions in Media Lengua, a Lexicon-Grammar mixed language ${ }^{1}$ found in the Northern Ecuadorian region of Imbabura consisting of Quichua $^{2}$ morphosyntax and Spanish vocabulary (Gómez Rendón, 2008). According to Muysken (1981), who studied an earlier variety of Media Lengua in a different region of Ecuador, Media Lengua was formed through relexification. In this process, nearly all Quichua lexical items were systematically replaced by a phonological shell borrowed from Spanish, which "adopts the meaning and use of the element in the receptor language for which it is substituted" (Muysken, 1981:55). ${ }^{3}$ Typologically speaking, Quichua and Spanish are fundamentally different: While Quichua is a head-final language (employing postpositions), Spanish is a head-initial language (using prepositions).

On the basis of the clear separation between Quichua morphosyntax and Spanish vocabulary that characterizes this mixed language, Media Lengua proves to be an excellent testing case for examining the status of adpositions as a linguistic category. The reasoning is as follows: Given that Media Lengua conserves Quichua morphosyntax and incorporates only relexified material from Spanish, the occurrence of Spanish prepositions would indicate that they carry lexical features (Dikker, 2008). Their exact locus in the utterance, i.e. whether they surface as pre- or postpositions, is predicted by Muysken's

1 For more details on mixed languages, see Bakker and Mous (1994), Bakker and Muysken (1994), Matras (2000), Matras and Bakker (2003), Meakins and Stewart (forthcoming) among many others.

2 Quichua/Kichwa usually refers to the Ecuadorian varieties of the language, while Quechua is used for the Peruvian dialect or the language family.

3 Other processes that have been suggested to be involved in the development of Media Lengua are, for example, translexification, adlexification and lexical freezing (Muysken, 1981; Gómez Rendón, 2008; Shappeck, 2011). 
(1981) relexification hypothesis. Hence, if Quichua postpositions are a lexical category and relexification is the mechanism that produced Media Lengua, these Quichua postpositions should be relexified with Spanish phonological shells but maintain their head-final spot in Media Lengua. If, on the other hand, Spanish prepositions occur in a head-initial spot in Media Lengua, this would be evidence against the relexification hypothesis - at least as concerns adpositional phrases. If all adpositions in Media Lengua are of Quichua origin, then, by definition of Media Lengua, they should form a grammatical category. Along the same lines, if Spanish prepositions are regarded to be grammatical, they should not occur in Media Lengua. Thus, mixed languages such as Media Lengua, even though they remain to the present day largely understudied, may be particularly suitable to refine linguistic theories due to their extraordinary linguistic profile (see also Lipski, 2016).

This paper reports recent field research data collected in two tasks: 72 trilingual speakers of Quichua, Media Lengua and Andean Spanish from three communities (Angla, Casco Valenzuela and Pijal, all located in Imbabura, Ecuador) participated in a video description task in Media Lengua and a translation task from only Quichua or Spanish into Media Lengua. It will be argued that the data show a clear split between lexical and functional adpositions in Media Lengua, providing evidence that this linguistic category is not homogenous and unified.

The results indicate that the majority of adpositional phrases are headed by Quichua postpositions in fulfillment of Quichua structural requirements, even in translations from Spanish into Media Lengua, supporting the notion of Quichua simple postpositions as functional items. Media Lengua complex adpositional phrases show a dual-language realization with a Spanish lexical item occupying the spot of a relexified Quichua lexical item, thus retaining the syntactic structure of Quichua complex postpositions. These results also support the claim that Media Lengua can be defined as a mixed language characterized by relexification - at least in terms of adpositions. On a more general level, this suggests that Media Lengua across communities is systematically framed by Quichua morphosyntax.

\section{Imbabura Media Lengua}

Media Lengua, an Li-oriented, ${ }^{4}$ Lexicon-Grammar mixed language was first observed by Muysken in the late 197os in the Ecuadorian Highlands (Muysken,

4 Muysken (2013:718) discusses L1-oriented mixed languages as resulting fom limited access to the lexifier language (in this case, Spanish). Other outcomes of language mixture may be 
1981, 1997, 2013; Meakins and Stewart, forthcoming). While Muysken's first descriptions documented Salcedo Media Lengua, a variety of Media Lengua in the Cotopaxi region of Ecuador close to the town of San Miguel de Salcedo (see Shappeck, 2011), Media Lengua has also been encountered in other areas of Ecuador: The two less documented Loja and Cañar Media Lengua varieties (Muysken, 1997) ${ }^{5}$ and Imbabura Media Lengua, spoken in the Northern Ecuadorian province of Imbabura (Gómez Rendón, 2008; Stewart, 2011, 2013, 2015; Lipski, 2016).

Some researchers believe that Quichua-Spanish language contact has created a continuum of hispanized Quichua and quichuasized Spanish local varieties (Shappeck, 2011), whereas others have noted that "[a]ll Quechua dialects have borrowed heavily from Spanish, up to roughly $40 \%$, but there are no dialects which borrowed more than 40\%" (Bakker and Muysken, 1994:44; Lipski, 2017). Be that as it may, Media Lengua occupies a prominent spot among any of these local vernaculars due to its extraordinarily large amount of incorporated Spanish lexical items (approx. 90\%) and its striking systematicity. Compared to the Salcedo variety, which is generally assumed to be more admissive of Spanish structures (Muysken, 1997; Shappeck, 2011), Imbabura Media Lengua, ${ }^{6}$

\begin{tabular}{|c|c|c|c|c|c|c|c|c|}
\hline \multirow[t]{2}{*}{$(1)$} & \multirow[t]{2}{*}{ Media Lengua: } & Mujer-ca & \multicolumn{4}{|c|}{ semilla-cuna-ta tierra-wan } & \multicolumn{2}{|r|}{ cubri-n. } \\
\hline & & woman-TOP & seed-P & $A C C$ & earth-wit & & & cover-3SG \\
\hline \multirow[t]{2}{*}{ (2) } & Spanish: & La mujer & cubre & las & semillas & con & la & tierra. \\
\hline & & DET woman & covers & DET & seeds & with & DET & earth \\
\hline \multirow[t]{2}{*}{$(3)$} & Quichua: & Warmi-ca & muyu-c & na-ta & alpa-war & & quilp & \\
\hline & & woman-TOP & seed-P & $A C C$ & earth-wi & & cove & $3 S G$ \\
\hline
\end{tabular}

L2-oriented mixed languages (with a stronger L2 presence), compromise mixed languages (with clear functional divisions between the respective input languages) or the usage of universal communicative strategies (such as reduplication).

5 It is not clear whether these two varieties still exist. Muysken's own descriptions of both varieties are limited (Muysken, 1997).

6 Sometimes also called chaupi shimi/chaupi lengua 'half-language', chapu shimi 'mixed language', chapusha-chapusha 'mixed up/broken', quichuañol or yanka shimi 'useless language' (yanka shimi may also refer to Quichua) or our dialect by the speakers themselves (Lipski, 2016; Stewart, 2011). 
the focal point of this paper, has been described as more conservative of Quichua morphosyntax (Gómez Rendón, 2008). The examples in (1-3), taken from the present corpus, ${ }^{7}$ illustrate the replacement of Quichua lexical roots with Spanish ones and the retention of Quichua morphosyntax, characteristic of Media Lengua:

The communities in the Imbabura province where Media Lengua is spoken include Angla, Casco Valenzuela and Pijal. These small villages close to San Pablo del Lago are only a short bus ride apart; Angla and Casco Valenzuela lie on opposite sides of a valley which can be crossed by foot in less than 30 minutes (see Fig. 1). Even though they are in such close proximity, only very few studies have conducted research across these communities (Lipski, 2016).

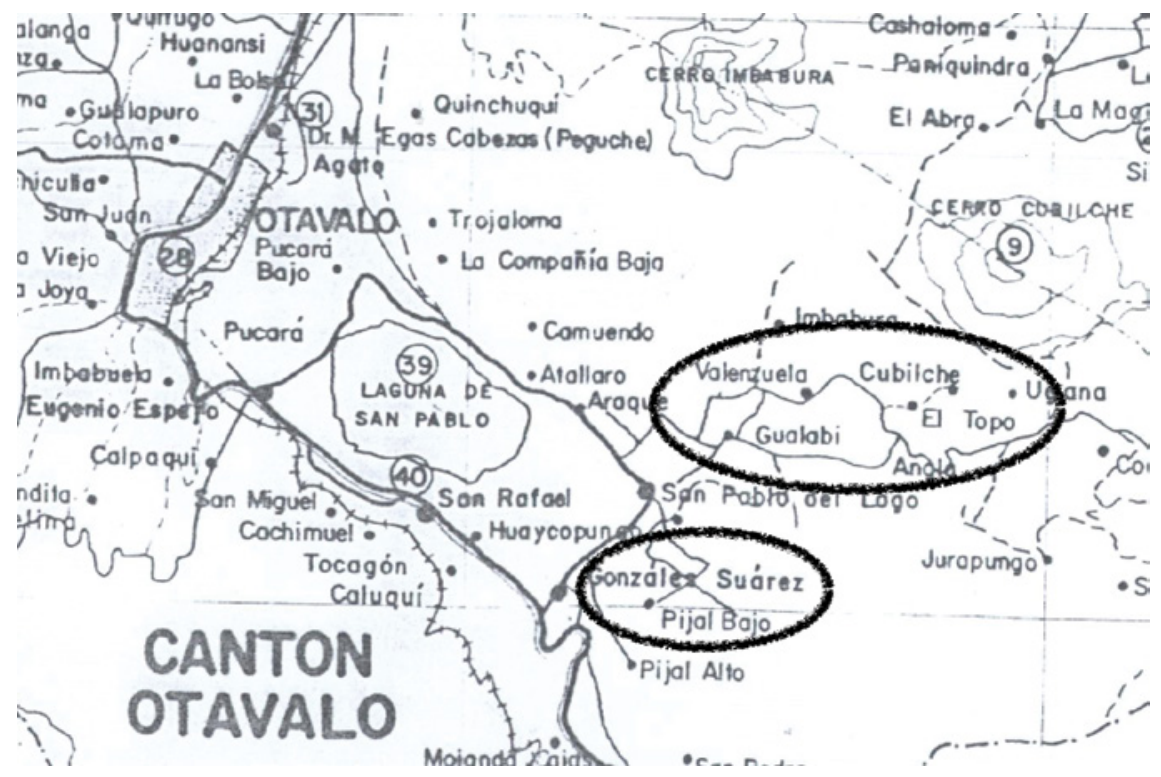

FIGURE 1 Location of Media Lengua-speaking communities close to Otavalo, Imbabura province, Ecuador.

7 A transcription of selected responses to the video description task from one participant (a female high school student from Casco Valenzuela) is included in the appendix. 
Tales from numerous participants in this experiment indicate that family and commercial ties brought Media Lengua from Pijal to Angla and from there to Casco Valenzuela. ${ }^{8}$ Thus, the Media Lengua varieties in Imbabura can be assumed to be very closely related. How Media Lengua was brought to Pijal or whether it developed there autonomously has yet to be investigated (Stewart, 2011).

As briefly outlined in this section, Media Lengua's unique linguistic configuration provides an exceptional opportunity for analyses aimed at grammatical categories (Lipski, 2016), particularly the ones that have not been clearly defined, such as adpositions.

Adpositions as a Linguistic Category

Adpositions are among the most controversial linguistic categories. Hagège (2010:8) defines them, similar to case affixes, as unanalyzable or analyzable linguistic units marking the grammatical and semantic links between two items that they put in relationship with each other. Their linguistic behavior, briefly summarized in the following paragraphs, can be described from a syntactic, morphological or semantic perspective; yet, none of these descriptions by themselves appear to be sufficient to clearly and completely explain their nature as a category.

(4) En año 1986-pi

(taken from Dikker, 20o8: 149)

in year 1986-in

'In the year $1986 \ldots$...'

(5) Aventaron en agua-ta threw in water-Acc

'(They) threw (them) in the water.'

8 It has been reported that Quichua and Media in Pijal is mostly spoken by older residents, while younger speakers seem to prefer Spanish (Lipski, 2016; Stewart, 2011). Others claim that Pijal is even monolingual (Gómez Rendón, 2008); the present experiments as well as Lipski (2016) and Stewart (2011) prove differently. In Casco Valenzuela and Angla, the presence of Quichua appears stronger and even young speakers (interviewed at a local high school in Topo) are proficient in Quichua and Media Lengua. (Rural Andean) Spanish is spoken by all participants. The sociolinguistic profile of the three communities is so incredibly diverse (ranging from some participants reporting that they learned Media Lengua as their Li to others claiming that they invented the language themselves when their children went to school) that this merits a more detailed description in future literature. 
Firstly, adpositions can occur in various syntactic positions. Prepositions precede the unit they govern, postpositions follow the governed term, ambipositions and circumpositions occupy both places (in the case of the latter, both pre- and postpositions appear concurrently). In the contact zone analyzed here, the two typologically dissimilar languages Quichua and Spanish produced a mixed language, Media Lengua. Given that Quichua is typologically classified as a postpositional language and Spanish as a prepositional language, one question to be answered in this paper is how adpositions will be realized in the mixed language.

Previous studies on Quichua-Spanish language contact outcomes found that prepositions either alternate with postpositions or occur in double constructions, such as the ones exemplified in (4) and (5).

Dikker (2008), who finds both alternating adpositions and double constructions, analyzed a 6000 word interview in Media Lengua with a member of the community Casco Valenzuela and interprets her findings as evidence in favor of Media Lengua loosening its Quichua morphosyntactic frame towards accepting more Spanish-like structures. Sánchez (2012), who finds double constructions as well, conducted an experiment with Peruvian bilingual children aimed at eliciting naturally occurring code-switches. She concludes that double constructions in code-switched sentences are the result of merged mapping strategies and that Quechua postpositions should be analyzed as case markers and not postpositions. While this is a very interesting proposal and certain Quechua postpositions are in fact syncretistic with some case affixes (e.g. Quechua -man 'to' can be interpreted as the dative case marker or the directional (DIR) postposition), a categorization of Quichua postpositions as case affixes for the present study does not appear to be necessary nor fruitful (for an alternative approach, see Muysken, 1981). ${ }^{9}$

Secondly, adpositions can be morphologically described as simple (e.g. stative and directional monomorphemes like at, to, from) or complex (multimorphemes like in front of, under, next to, inside, etc.). In an abstract analysis, Cinque (2010) points out that complex locative adpositions such as under the table can be assumed to be modifiers of a PLACE DP, selected by a possibly unpronounced stative adposition (at), as displayed in (6):

(6) $\left[_{\text {PPstat }}(\right.$ at $)\left[{ }_{\text {DPplace }}\left[\mathrm{XP}\right.\right.$ under $\left[\mathrm{X}\left[_{\mathrm{PP}} \mathrm{P}\left[{ }_{\mathrm{NPplace}}\right.\right.\right.$ the table $\left.\left.\left.\left.\left.[\mathrm{PLACE}]\right]\right]\right]\right]\right]$

$9 \quad$ It should be pointed out that the double constructions Sánchez (2012) finds can be more elegantly analyzed if one of the two adpositions (e.g. the postpositions) are, as case markers, only the spell-out of agreement than actual heads of the projection. There cannot be two (oppositely directed) heads in a projection. 


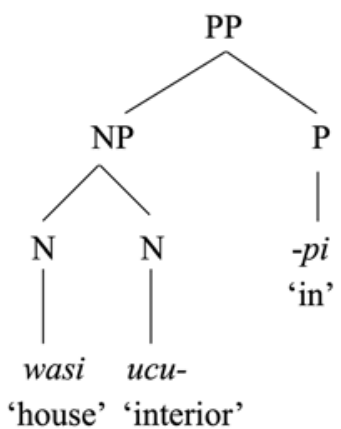

'in an interior, which is a house'

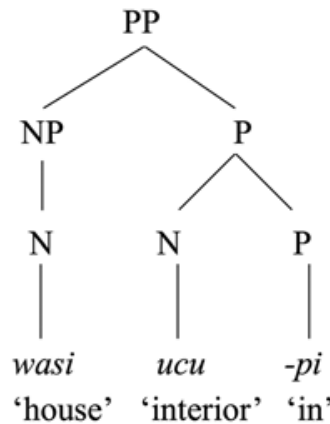

'inside the house'

FIGURE 2 Schematic representation of the derivation of complex postpositional phrases (right tree) from compound nouns (left tree) with wasi ucu-pi 'inside the house' as an example (adapted from Cole, 1982: 120).

This analysis shows that the morphemes combined into complex adpositions may be interpreted as heads of different maximal projections (Koopman, 2010; den Dikken, 2010; Grimshaw, 200o). The structure in (6) could be easily applied to typologically different languages by different types of movement and (non)pronunciation of certain components (Terzi, 2008). As concerns OV languages such as Quichua, Cinque (2010) suggests that the syntactic structure of postpositional phrases would correctly be portrayed by raising the PLACE DP around the 'axial adposition,, ${ }^{10}$ followed by additional raising and pied-piping around the stative adposition $(a t)$. All components are pronounced in Quichua.

Moreover, the historical development of complex adpositions in Imbabura Quichua has been described as resulting from compound nouns: Postpositional phrases such as Quichua wasi ucu-pi 'inside the house' appear to have been derived from a head-final noun compound wasi ucu 'house interior' (Cole, 1982), as illustrated in Fig. 2. It follows from Cole's (1982) analysis that ucu- (from a synchronic perspective) is part of the locative expression and modifies the stative locative postposition - $p i$ ' in', which can then be interpreted as 'inside the house'. This is an important argument as it presents a clear view as to why complex adpositions are multimorphemic and display noun-like properties, as has been claimed to be true for 'axial adpositions' in general (cf. Jackendoff, 1996).

Thirdly, according to their respective semantic domains, adpositions may be assumed to be part of the domain of core meanings (e.g. English possessive of), the domain of spatio-temporal meanings (e.g. between) or the domain of non-spatio-temporal meanings (e.g. without, despite) (for a more exhaustive

$10 \quad \operatorname{In}(6)$, under would be the axial adposition since it projects a spatial vector from the reference point, the table, (Jackendoff, 1996; O'Keefe, 1999; Zwarts and Winter, 2000; Zwarts, 2003). 
description: Cinque, 2010; Hagège, 2010). Even though, cross-linguistically, adpositions are rarely attested as core function markers and are much more frequent in non-core functions (Hagège, 2010), this classification reiterates the proposals from above that point at the functional similitude of case markers and adpositions.

For the purposes of this paper, the most relevant distinction of adpositions concerns the lexical-functional divide. According to this view, which is still a matter of much debate, adpositionsfall into two groups that roughly correspond to the simple and complex structures already mentioned:lexical and functional.

In the example wasi ucu-pi 'inside the house', the complex adposition is composed of a lexical part (the part that originated in the compound noun, e.g. $u c u$ 'interior') and a functional part (the stative locative postposition - $p i$ ' 'in'). Other considerations that have been put forth in the classification of adpositions are, for example, whether they lack semantic content or whether they are limited in number and hardly change through time, that is, whether they are members of a closed or open class (e.g. Abney, 1987; Rauh, 1991; Cinque, 2010; Asbury et al., 2008). However, these criteria are less clear-cut as they may seem at first sight. The arbitrariness of semantic content becomes apparent if adpositions are contrasted with other functional categories such as tense and aspect morphemes. As Rauh (1991) illustrates, it stands to reason that replacing one spatial adposition for another may have a crucial impact on communicating spatial location. Nevertheless, some researchers suggest that their semantic contribution is merely "second-order" (Abney, 1987: 44), somewhat more abstract and less descriptive than what is generally assumed to be the defining characteristic of lexical categories. Other criteria like limited number and diachronic robustness do not seem very accurate either since the temporal, spatial or grammatical relationships that could be encoded by adpositions are by default rather limited and the development of complex postpositional phrases, as outlined above, can easily be related to grammaticalization processes like derivation, which could productively add items to the class (e.g. Beckner and Bybee, 2009; Bybee, 2010).

Generativist accounts describe adpositions as case-assigners and heads of maximal projections with the features [-N,-V] (Chomsky, 2015; Jackendoff, 1977), thus acknowledging that they should be part of one comprehensive classification together with other lexical classes like nouns and verbs. Presenting arguments against both a feature-based and a semantic classification of adpositions, Déchaine (2005:7) suggests that adpositions are similar to the traditional lexical categories even though they epitomize the "elsewhere case": Adpositions, she argues, are syntactically multifunctional and in fact somewhat akin to light - or in Zwarts's (1997: 3) words, "functional" - verbs such as copulas and auxiliaries. 
Abney (1987), skeptical of a distinction implying a link between the two features $[ \pm \mathrm{N}]$ and $[ \pm \mathrm{V}]$ for adpositions, assumes instead two major features $[ \pm \mathrm{F}]$ (a functional category) and $[ \pm \mathrm{N}]$ and treats adpositions as unspecified for $[{ } \mathrm{F}]$, right on the border between thematic and functional elements. Along the same lines, Baker (2003) states that adpositions appear to be more closely related to functional categories (e.g. determiners, pronouns, complementizers) than to lexical ones (e.g. nouns, verbs, adjectives). Muysken (2008), not convinced by Baker's (2003) arguments, presents evidence from various languages, including Ecuadorian Quichua, which, he claims, does not possess lexical elements of the category P. As already explained above, however, other authors provide evidence for lexical items that are part of this category in Quichua (e.g. Cole, 1982). This paper extends this claim to the mixed language Media Lengua, which shows a dual-language realization of complex adpositions according to a lexical-functional split.

Offering a solution to the theoretical problem that adpositions pose, Zwarts (1997) proposes a gradient scale with two independent lexical and functional dimensions. He concludes that the assumption that adpositions are a homogeneous category is false and, rather, that there are core adpositions (which presumably are the functional ones) and some peripheral items (the ones that are lexical) $)^{11}$ - a two-way split that is exhibited by many languages (Asbury et al., 2008). This is an interesting hypothesis that could easily be applied to Imbabura Quichua. With respect to Media Lengua, a language based on Quichua morphosyntax while incorporating much of the Spanish lexicon, the picture becomes more intriguing. In view of the still unsettled debate on the status of adpositions, the analysis of a mixed language which conveniently shows a split between grammar and lexicon can provide useful naturalistic evidence to add to the debate. The results of the experiment reported here show a clear split between lexical and functional items in this linguistic class, manifested in the dual-language realization of complex items.

In conclusion of this brief description of the state of affairs, other researchers also analyzing less prototypical linguistic areas have adequately pointed out that the "ambiguous status of [ad]positions in current syntactic theory reflects a real problem, especially for empirical investigations in this domain" (Froud, 2001: 2). In her paper, Froud (2001) presents evidence from neurolinguistics suggesting that aphasic patients that showed problems articulating functional items also had trouble with adpositions. Similarly, Chan (2008) finds that

11 Grammaticalization theory views the "reanalysis of a lexical item as a grammatical item" as the origin of any grammatical item (Beckner and Bybee, 2009: 32). In this view, lexical items undergo a process of derivation, that is, a category change (e.g. from noun to postposition, as exemplified in Fig. 2). 
P patterns like other functional categories in code-switching. This shows that data from peripheral linguistic disciplines such as the study of aphasia or language contact not only adds valuable insight into the matter but also crucial testing ground for syntactic theories.

In summary of all the points mentioned so far, the experiments described below were guided by the following research questions:

- Are adpositions a lexical or functional category? Is this category homogeneous or heterogeneous?

- Do adpositions in Media Lengua occur as prepositions, postpositions or both?

- Is there evidence in favor or against Muysken's (1981) relexification hypothesis as concerns adpositions?

- Does the realization of adpositions change in different tasks (video description vs. translation)?

These research questions lead to multiple hypotheses:

- If adpositions are a functional category, all Media Lengua adpositions should be of Quichua origin. If they are a lexical category, they should be relexified.

- If adpositions are a homogeneous category, they should pattern uniformly in syntactic structures.

- If Media Lengua was brought about by relexification, Spanish items should occur (if they occur at all) in the head-final spot usually occupied by Quichua postpositions.

- If participants are exposed to syntactic constructions in a translation task, their responses may change due to priming.

\subsection{Experiment 1: Video Description}

In this video description task, 72 participants ( 63 female, 9 male $^{12}$ adults from all age ranges, four older adolescents) trilingual in Quichua, Media Lengua and

12 Participants were mostly female since men usually are at work during the day and, thus, female participants were more available than men. Future research needs to examine the extent to which there is gender-based sociolinguistic variation in Media Lengua. Based 
Spanish ${ }^{13}$ participated in a video description task, rendering about fifteen minutes of recorded speech per participant. Eight participants were excluded after participating as their proficiency in Media Lengua appeared dubious, they displayed considerable trouble completing the task or their response was unclear and could not be transcribed with confidence. The data of the remaining 64 participants ( 57 female, 7 male) was analyzed: Thirty-two participants were from Angla, twenty-one from Casco Valenzuela and eleven from Pijal, all located in the province of Imbabura, Ecuador.

Participants were asked to describe twenty-two short video clips (each between 13 and 59 seconds long) in Media Lengua, commenting with as much detail as possible as they were watching. These videos either showed the preparation of a locally known dish or a locally common practice, such as dancing the Inti Raimi Dance during the Festival of the Sun. Some clips were taken from the locally known movie The little shepherd from Otavalo (Spanish: El pastorcito de Otavalo) and, as such, they seemed suitable to elicit the use of adpositional phrases. All video clips were cut in order to display a complete and cohesive action and did not contain any written or spoken language (the audio track was cut out manually in an open source video converter) that could interfere in the activation of a specific language during production. Instructions were given in Quichua, Spanish and Media Lengua and participants were explicitly prompted to describe people, objects or actions in the videos. If participants paused for an extended period of time, they were asked specifically what a certain person in the video was doing. Likewise, if they did not respond in Media Lengua but used Quichua in their descriptions, they were reminded to respond in Media Lengua. All participants saw the video clips in the same order. A sample response provided by a female high school student from Casco Valenzuela is included in the appendix.

During the task, other participants or participants' families were present in the room and overheard both the instructions and some participant responses. This is the natural result of the participants being interrupted in their daily routines to participate in this study. Since the goal of the study was not explicitly mentioned to any participant nor easily inferable from the task, it appears unlikely that this should have influenced participant responses. Furthermore,

on my impressionistic observations, I do not expect there to be vastly different usage patterns based on gender, at least as concerns syntactic constructions.

13 The author spoke Spanish with all participants. Participants were selected based on selfreports of language proficiency in Quichua as well as Media Lengua. No further language proficiency tests were conducted. 
this is the environment that most participants are used to in their daily lives and feel most comfortable in.

Responses were coded according to type (Spanish-like, Quichua-like, Other) and complexity of adposition (Simple, Complex). Examples of all types are provided in (7-9); lexical morphemes in complex adpositions are bolded:

(7) Spanish-like:
a. Simple:
desde/de Quito
from Quito
'from Quito'
b. Complex:

atrás de la casa
behind of DET house
'behind the house'

(8) Quichua-like:
a. Simple:
casa-pi
house-in
'in the house'
b. Complex:
casa-ñawpag-pi
house-in.front.of-in
'in front of the house'
c. Relexified: casa-adelante-pi
house-in.front.of-in
'in front of the house'

(9) Other:
a. Simple:
hasta Quito-caman
to Quito-to
'to Quito'
b. Complex: para arriba-man
toward above-toward
'upward'

Observe that 'Relexified' is included in the category 'Quichua-like' since all relexified adpositions were complex and framed by a Quichua simple functional adposition (e.g. - $p i$ 'in'). Thus, examples (8b) and (8c) are structurally (and semantically) identical except for the language of the lexical morpheme: In (8b), the lexical morpheme is not relexified and surfaces with a Quichua root (ñwpag 'in front of'); in (8c), the lexical morpheme is relexified and surfaces with a Spanish root (adelante 'in front of'). 
Furthermore, the items included in the category 'Other'

(a) show switches in word order (e.g. casa-pi alrededor instead of casaalrededor-pi 'around the house'; encima mesa-pi instead of mesaencima-pi 'on top of the table'), ${ }^{14}$

(b) are bare, that is, complex in nature but not (well-)framed by a simple adposition (e.g. atrás niño 'behind the boy'; hombre atrás 'behind the man'), or

(c) are double constructions either adding new semantic content or reinforcing identical semantic content (e.g. al frente de mi casa-pi 'in front of my house'; para adentro-man 'inward', respectively).

Spanish frozen items like mercado de Otavalo ('market of Otavalo') were either coded as 'Other' if they were framed by a Quichua postposition (e.g. Directive -man 'to') or as 'Spanish-like' if they were framed with a Quichua accusative marker (i.e. the accusative marker was treated as non-existent in this categorization). Given the low rate of occurrence of these tokens, they will not be described in more detail.

\subsubsection{Results}

In this task, a total of 2,156 Media Lengua adpositional phrases were analyzed. ${ }^{15}$ If participants repeated the same adpositional phrase in one sentence, both phrases were included in the analysis.

Figure 3 displays the number of responses according to type and complexity of adposition. The results clearly show that $89 \%$ of adpositional phrases $(\mathrm{n}=$ $1,925)$ employed simple Quichua postpositions. Only 28 complex tokens ( $1 \%$ of the data) were realized with a Quichua lexical morpheme, while 125 (6\% of the data) showed a lexical morpheme relexified from Spanish. In free discourse, complex adpositions occur rarely since it is often unnecessary for successful communication to specify the location of a particular object in detail. Hence, it is not surprising that the vast majority of tokens are simple adpositions. Nonetheless, there is a clear trend towards relexifying the lexical morpheme in complex adpositions while retaining the Quichua simple postposition as the

14 This can easily be accounted for if, as described in section 3, complex postpositional phrases originate in noun compounds. The present corpus includes numerous examples of modifier-noun phrases with switched word order (e.g. grande olla-pi or olla grande-pi 'in the big pot'), which probably originates in the typological differences between Quichua and Spanish. Future research should target these structures for more insight into this structural variation.

15 This number does not include combinations with ahi 'there' or aqui 'here' (such as ahi-pi 'there', ahi-manta 'from there', ahi-man 'to there', also relexified from Quichua chay-pi 'there' or cay-pi 'here', etc.), which occured abundantly in the present corpus $(\mathrm{n}>1000)$. 


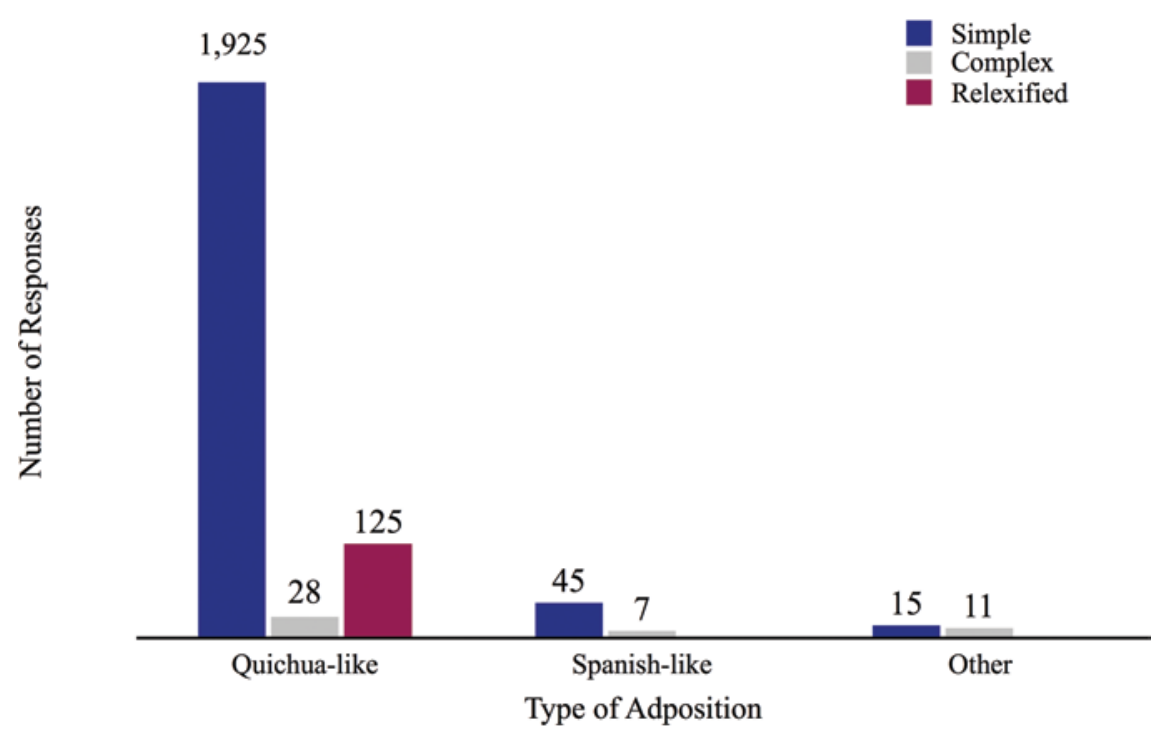

FIGURE 3 Number of responses in the video description task according to type and complexity of adposition (total $n=2,156$ ). Since the absolute value for Quichua-like simple adpositions amounts to 1,925 tokens, the height of the respective bar was modified for purposes of illustration.

head of the projection. As such, these results provide evidence in favor of the relexification hypothesis by Muysken (1981) for adpositional phrases: A Spanish lexical morpheme occupies the spot which in Quichua would have been occupied by a lexical morpheme while the Quichua simple (functional) postposition pertains to the morphosyntactic frame and is the head of the projection.

Furthermore, only $5^{2}$ tokens overall ( $2 \%$ of the data) were realized completely in Spanish; none of the simple Spanish prepositions occurred as postpositions (e.g. *Quito desde 'from Quito'). This shows that Imbabura Media Lengua is nearly uniformly framed by Quichua morphosyntax, contrary to what Dikker (2008) claims. Note that, without providing detailed results indicating the degree to which Spanish prepositions were incorporated in her corpus, she argues fervently that her results are “incompatible with Muysken's (1981) model of relexification" (Dikker, 2008: 151). This is not what the present study finds. In light of the small number of Spanish simple prepositions incorporated in Media Lengua in the present data set, it can safely be argued that they do not carry lexical features which would have made them eligible for relexification. Only the lexical morphemes in complex adpositions carry lexical features and can be relexified. This is exactly what Muysken (1981) predicts. 
The present results also stand in direct contrast with the findings from previous studies as concerns the occurrence of double constructions (Dikker, 2008; Sánchez, 2012). The limited number of double constructions elicited in this experiment (coded as part of the category 'Other', $n=26$, produced by various participants from all three communities) does not provide enough direct evidence for converging syntactic mapping strategies in Imbabura Media Lengua. Rather, these few tokens, the majority of them hapax legomena, can be regarded as on-line speech production errors, not reflective of the very conservative underlying morphosyntactic frame that is so distinctly apparent in $97 \%$ of the data (considering all Quichua-like tokens). This finding is in line with previous research describing blended structures as clearly marked and dispreferred (Goldrick et al., 2016). Furthermore, other potentially doubled constructions such as jugo de naranja-wan 'with orange juice' can neatly be accounted for by their frozen status in these collocations. Finally, constructions (also coded as 'Other') which are unframed or show switches in word order (e.g. encima mesa-pi instead of mesa-encima-pi 'on top of the table') are unsurprising from a usagebased perspective, where constituent structure is "gradient, mutable, and emergent from domain-general processes", and directly related to the frequency of the individual subparts of the construction (Beckner and Bybee, 2009: 29).

Since the results for elicited free speech are so strikingly clear-cut, statistical analyses were only conducted in comparison with experiment 2 . These results across tasks are reported in section 4.3.

In light of these results, the question arises whether a different task, such as translations, would lead to a different outcome. If participants are asked to translate phrases from Spanish into Media Lengua, recent exposure to Spanish structures may lead to the inclusion of more Spanish-like structures in Media Lengua responses (Hartsuiker and Westenberg, 2000; Hartsuiker et al., 2004; Pickering and Ferreira, 2008; Gries and Kootstra, 2017). This phenomenon is known as structural priming 16 and has been described as a "quasi-neurological energizing, excitation, or threshold reduction that persists over time, increasing the probability that the activated [...] information will influence subsequent cognitive processes" (Bock, 1986:356). The priming of specific syntactic structures, has also been found to show an effect cross-linguistically: Hartsuiker et al. (2004), for instance, demonstrated that Spanish-English bilinguals tended to employ more passive sentences in English when they had been

16 In light of the characteristics of Media Lengua, I follow Pickering and Ferreira (2008), who recommend the use of the term structural priming instead of syntactic priming or syntactic/structural persistence as not all abstract linguistic priming may be syntactic or the result of purely syntactic representations. 
primed by a Spanish passive sentence. This is argued to be the result of different combinatorial nodes being activated at the same time and one of them being selected more favorably in cases of priming. In order to test this hypothesis, experiment 2 was conducted.

\subsection{Experiment 2: Translation task}

In this second experiment, the same participants as in experiment 1 were randomly chosen to translate 30 sentences from either only Quichua or only Spanish into Media Lengua. Data from one female participant from Angla could not be analyzed as due to experimental error her responses were not recorded. The final data set contained responses from 32 participants which translated from Spanish and from 31 participants which translated from Quichua. All translation sentences contained at least one adpositional phrase and varied in length (e.g. less than 20 Spanish words, see appendix) to obscure the purpose of the task. Some sentences were modeled on actions participants saw during the video description in experiment 1 ; others concerned normal every day activities like driving to Quito or preparing a dish. All sentences followed the analysis design based on the five basic spatio-temporal adpositions outlined in Dikker (2008) and Cole (1982), which correspond to the basic semantic categories illustrated in Mackenzie (2001):

- Locative at [Quichua (IQ) -pi, Spanish (S) en],

- SOURCE from [IQ -manta, S de],

- PATH via [IQ -ta, S por],

- DiRection to [IQ -man, $\mathrm{S} a]$,

- ALLATIVE toward [IQ -caman, S para/hacia/hasta].

The stimuli contained at least five instances of each of these categories; the target responses to these categories employ simple adpositions. Other adpositions that were randomly included in the task are, for instance, the complex LOCATIVE items opposite of [IQ ñawpag-pi, S frente a] and behind [IQ washa-pi, $S$ detrás de] as well as various other simple adpositions like INSTRUMENTIVE with [IQ -wan, S con]. Since the task was not primarily designed to control for complexity of adposition, two Quichua sentences contained complex adpositions while their Spanish counterparts employed simple adpositions. The overall number of complex spatial adposition in the Spanish stimuli is $(\mathrm{n}=3)$ and in the Quichua sentences $(n=5)$. In addition, some sentences randomly included TEMPORAL adpositional phrases such as in the afternoon [IQ chishi$p i$, S en la tarde] or at 3 oclock in the afternoon [IQ quimsa pacha chishi-pi, S a las tres de la tarde], PUR POSIVE adpositions in order to [IQ -ngapag, S para] 
or TEM PORAL adpositions that combine with a verb, e.g. after cooking [IQ yanushcaquipa, S después de cocinar].

Participants were instructed that they were translating these sentences so that the present researcher could learn how to correctly say them in Media Lengua. Participants were not corrected if they translated only the main message of the sentence and left out part of the sentence in their translation. They were reminded to speak only Media Lengua if their response employed Quichua and they could listen to the stimuli as many times as they wished. All translation sentences were designed in Spanish, then recorded and translated into Quichua by a male, trilingual speaker of Ecuadorian Spanish, Imbabura Quichua and Imbabura Media Lengua living in Angla. As for experiment 1, all participants listened to the stimuli in the same order; the semantic categories in the stimuli occurred in random order. The fact that both Spanish and Quichua were source languages in this task, allows for a comparison of any effects that might result from hearing the respective adposition in the source language; however, a within-speaker comparison will not be possible since each participant only translated from one of the two languages. As the results in section 4.3 indicate, whether the input language was Spanish or Quichua did not turn out to have a major effect on participant responses, rendering a within-speaker comparison superfluous. A complete list of sentences used in this task is included in the appendix. As for experiment 1, other participants or participants' families were present in the room and overheard both instructions and some participant responses. The coding procedure was the same as for experiment 1.

\subsubsection{Results}

In this task, a total of 2,237 Media Lengua adpositional phrases were analyzed. The results are displayed in Fig. 4. Two tokens were excluded due to being unclear as a result of reformulation or hesitation. If participants repeated the same adpositional phrase in their response sentence, both phrases were included in the analysis. Indications of time such as 3 de la tarde-pi 'at 3 o'clock in the afternoon' occurred without exception as frozen tokens employing Spanish $d e$ 'in' while being framed by Quichua postpositions - $p i /$-ta 'at', and, in order to not skew the results, they were not included further in this analysis. Likewise, the randomly included PURPOSIVE adpositions in order to [IQ -ngapag, S para] or the TEMPORAL adpositions that combine with a verb, e.g. after cooking [IQ yanushcaquipa, S después de cocinar], were not analyzed in detail for this paper and will not be further discussed. ${ }^{17}$

17 As concerns the verb constructions, responses in both translation conditions employed unrelexified quipa (e.g. cocinashcaquipa) or relexified después (e.g. cocinashcadespués). 
Translation from Spanish

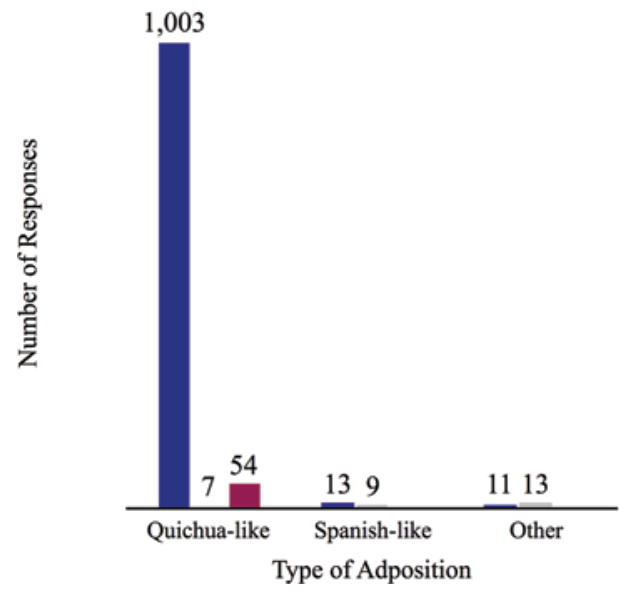

Translation from Quichua

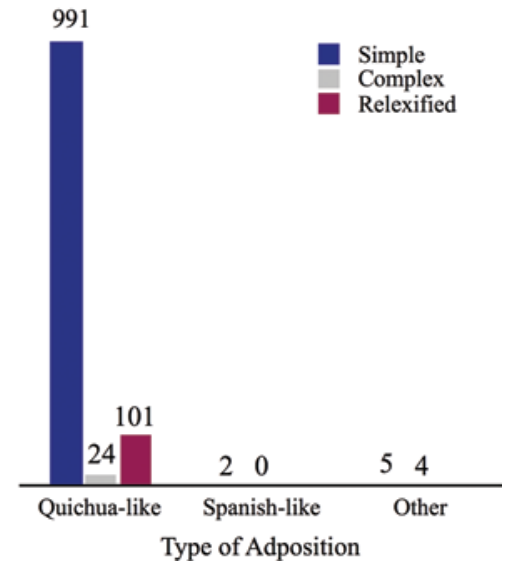

FIGURE 4 Number of responses according to translation language (total $n=2,237$ ).

As Fig. 4 shows, the results of the translation task mirror the overall pattern found in experiment 1. Regardless of semantic category, there is a higher overall number of Quichua simple postpositions in either translation condition (Spanish or Quichua). Observe that absolute numbers cannot be compared because participants were not prompted to translate the sentences word by word nor corrected if they omitted part of a sentence. The overall number of complex adpositions is comparatively low, which may be the result of participants translating a sentence containing a complex adposition with a simple adposition. As explained in section 4.1.1, it is rarely necessary to indicate the exact location of an item with a complex adposition and using a simple adposition often suffices. Yet, Fig. 4 displays that complex adpositional phrases, when included in responses, show a clear preference to occur with a relexified lexical morpheme, irrespective of whether participants are translating from Quichua $(\mathrm{n}=101)$ or Spanish $(\mathrm{n}=54)$.

Moreover, only 2 Spanish prepositions were elicited when participants translated from Quichua into Media Lengua. In other words, participants primed by Quichua were unlikely to incorporate Spanish tokens in their Media Lengua responses. However, the group primed by Spanish showed a minimal priming effect, rendering their performance slightly more similar to the less constrained speech elicited in experiment 1 . Recall that participants translated only from one language (either Quichua or Spanish) into Media Lengua; hence, personal preferences for a given structure - though unlikely - may also be a plausible interpretation of these results. Rather, it seems more likely that 
Quichua priming sentences can reinforce the Quichua morphosyntactic frame in Media Lengua responses while Spanish primes may lead to a more flexible morphosyntax. The same analysis appears to be accurate for the 'Other' responses; their number is lowest in the Quichua translation condition as well.

As concerns the relexified complex adpositions in this experiment, the results show a larger number of tokens in the Quichua translation condition $(n=101)$. If it is taken into account, however, that the sentences were not designed to control for complexity of adposition, as indicated in section 4.2, a comparison of these numbers would not be fruitful. However, the fact that the amount of relexified complex adpositions is not smaller in the Quichua translation responses suggests that participants are metalinguistically aware of how to construct a well-formed (that is, relexified) response in Media Lengua. Furthermore, this also indicates that participants can resist Quichua lexical priming.

In consideration of these results, it seems that recent exposure to a Spanish structure allows for a slightly more flexible Media Lengua morphosyntax, while exposure to Quichua can strengthen the Quichua morphosyntactic frame. Factors like structural priming have been suggested in previous studies as possible reasons to influence other morphosyntactic realms such as word order (e.g. Bock, 1986; Hartsuiker and Westenberg, 2000). Hence, it is no surprise that they should also account for the minor effects observed in the current data set. Since it has been argued that priming across languages is most successful when the languages in question share the same word order (Kootstra et al., 2010), this readily explains the low number of Spanish-like structures in translations from Spanish.

\subsection{Comparative Statistical Analysis}

Multiple statistical tests were conducted in R (R Core Team, 2016) in order to examine whether the occurrence of Quichua- or Spanish-like constructions was dependent on the task, that is, whether free discourse (video description task) or input language (translation task) had an effect on the realization of adpositions in Media Lengua. The distribution of observations across all tasks is shown in Table 1. Given that the category 'Other' contains a variety of responses that could not be clearly categorized, it will be not be included in the tests reported here.

Statistical tests comparing only the Quichua-like and Spanish-like constructions in the translation tasks show a significant difference depending on whether participants were translating from Spanish (Spanish translation) or Quichua (Quichua translation) (Chi-squared test: $X^{2}(1)=15.774, \mathrm{p}<$.oo1; Fisher's Exact Test: $\mathrm{p}<.001)$. There were significantly more Spanish-like constructions in translations from Spanish than in translations from Quichua. 
TABLE 1 Number of Quichua-like, Spanish-like and 'Other' constructions across tasks.

\begin{tabular}{|c|c|c|c|}
\hline & Quichua-like & Spanish-like & Other \\
\hline Video Description & 2078 & $5^{2}$ & 26 \\
\hline Spanish Translation & 1064 & 22 & 24 \\
\hline Quichua Translation & 1116 & 2 & 9 \\
\hline Total & $425^{8}$ & 76 & 59 \\
\hline
\end{tabular}

Tests comparing only the Quichua-like and Spanish-like constructions in the video description and the Quichua translation task also show a significant difference between tasks (Chi-squared test: $X^{2}(1)=21.591, \mathrm{p}<.001$; Fisher's Exact Test: $\mathrm{p}<$.001). There were significantly more Spanish-like constructions in video descriptions than in translations from Quichua. Moreover, tests comparing only the Quichua-like and Spanish-like constructions in the video description and the Spanish translation task did not show a significant difference between tasks (Chi-squared test: $X^{2}(1)=0.383, p>.5$; Fisher's Exact Test: $p>.5$ ). This can be interpreted to mean that production patterns are similarly admissive of Spanish-like constructions in these two tasks.

In sum, these results corroborate that, while Quichua-like structures are preferred regardless of the task, the occurrence of Spanish-like constructions may be significantly modulated by discourse context or priming.

\section{5}

\section{Discussion}

The main goal of this paper was to offer evidence from a mixed language to add to the discussion about the status of adpositions as a linguistic category. Media Lengua, a Lexicon-Grammar mixed language, is an excellent testing case for this endeavor. The principal prediction was that if Spanish prepositions occur in Media Lengua, by definition of this mixed language, they must be carrying lexical features. Furthermore, if this Spanish lexical material occurred as prepositions, it would provide direct evidence against Muysken's (1981) relexification hypothesis - at least as concerns adpositional phrases. According to this hypothesis, the Spanish phonological shell should take over the meaning and use of the relexified Quichua item, that is, it should occur in the spot of a postposition (Muysken, 1981).

The results presented for both experiments are clear: Adpositions in Media Lengua are consistent with a lexical-functional split, which is most 
prominently manifested in the dual-language realization of complex adpositions This is displayed in examples $(8 \mathrm{~b})$ and $(8 \mathrm{c})$, repeated here as $(1 \mathrm{ob})$ and (10c), with lexical morphemes in complex adpositions bolded.

(10) Quichua-like:
a. Simple:
casa-pi
house-in
'in the house'
b. Complex:
casa-ñawpag-pi
house-in.front.of-in
'in front of the house'
c. Relexified: casa-adelante-pi
house-in.front.of-in
'in front of the house'

The lexical components of complex adpositions (e.g. IQ ñawpag 'in front of') were relexified with Spanish phonological shells (e.g. S adelante 'in front of') while the functional components (e.g. IQ - $p i$ 'in') were realized in Quichua (10c). At the same time, simple adpositions occurred almost exclusively in Quichua and in their head-final position (10a); no simple Spanish prepositions were found in a postpositional spot.

In Media Lengua, the syntactic hierarchy between items in complex adpositional phrases (that is, their functional and lexical components) corresponds to the respective morphemes being derived from two different languages (Quichua as well as Spanish), which suggests that complex adpositions cannot be considered simple heads of a functional projection. Rather, the category of adpositions is heterogeneous and contains both functional and lexical elements that do not pattern uniformly in syntactic structures but stand in a hierarchical relationship. In line with current syntactic proposals, the projection of a lexical item is contained within a functional projection in complex adpositions (Corver, 2013). That is, complex adpositional phrases in Media Lengua behave according to the Functional Head Hypothesis, which claims that a lexical projection is dominated by a functional projection (FP) in an extended projection (Grimshaw, 2000). This is displayed in (11) (adapted from Corver, 2013:357):

(11) $\left[\left[_{\mathrm{PP}} \mathrm{P}\right]_{\mathrm{FP}} \mathrm{F}\right]$ (right-headed extended adpositional projection)

This is also in line with some proposals on code-switching, which argue that the language of a functional category determines the position of its complement (e.g. Chan, 2008; Myers-Scotton, 1993). 
Moreover, these results lend further strength to the claim that Media Lengua - at least in terms of adpositional phrases - can be defined as a mixed language characterized by relexification given that relexified complex adpositions mirror the syntactic structure of complex Quichua postpositions and that no grammatical items (that is, Quichua simple postpositions) are relexified by the respective Spanish simple items, as can be seen by comparing examples (10b) and (10c). From a semantic perspective, lexical morphemes in complex adpositions hence need to be carrying more semantic features than simple adpositions, making them elegible for relexification. The data presented here neatly reflects this difference in semantic content between lexical and functional adpositions as lexical items occur in their relexified form with a Spanish phonological shell while functional ones retain a Quichua phonological shell.

Overall, the Quichua morphosyntactic frame turned out to be very robust even in cases of priming in the Spanish translation task: Even in this condition, Quichua simple postpositions framed a large majority of adpositional phrases and Spanish prepositions were almost non-existent. It appears that recent exposure to Quichua in the translation sentences reinforced the Quichua morphosyntax in participants' responses. In the Spanish translation as well as in the video description, answers tended to be significantly more admissive of morphosyntactic variants. As such, these results are in line with findings in other studies that show that priming across languages is most successful when word order is shared (Kootstra et al., 2010; Goldrick et al., 2016). Clearly, headfinal Quichua and head-initial Spanish are too typologically different for this to have a major effect in translations from Spanish. Besides structural priming, the results from experiment 1 show that discourse context and informality may also be responsible for a somewhat relaxed shape of the morphosyntactic frame (Escobar, 2000; Gómez Rendón, 2008). More generally, the current study provides evidence that Media Lengua across communities is conservative and systematic in its use of Quichua morphosyntax (Gómez Rendón, 2008).

A final question that remains to be explored is how the different morphemes that build complex adpositions are stored in the mental lexicon of trilingual speakers of Media Lengua, Quichua and Spanish. Is there a separate Media Lengua lexicon? These questions have not been addressed in the literature in detail; I will only attempt to offer a brief discussion here as concerns adpositions and leave more detailed descriptions to future research.

Rauh (1991) offers a suggestion on how temporal and spatial adpositions, which are often homophonous but syntactically and semantically distinct, are stored in the monolingual lexicon. According to this view, these variants of adpositions are separate but not full mental entries which are interconnected by the shared property and arise through the change of single properties or the 
embedding in new contexts (Rauh, 1990: 205). Hence, for these temporal meanings, the same phonological matrix is mapped onto a different syntactic and semantic representation. A lexical rule connects the spatial and the temporal variant, maintaining the phonological form while changing the other properties accordingly (ibid. 205-217). Since the temporal variants of adpositions are, so to speak, context-specific variants of the same abstract representation, they can be regarded to be "allo-[ad]positions" (ibid. 219) - a type of allomorph.

I propose to extend this analysis to Media Lengua with some modifications: In Media Lengua, the relexified (e.g. S encima 'on top' in encima-pi 'on top of') and not-relexified (e.g. IQ ñawpag 'on top' in ñawpag-pi 'on top of') lexical morphemes that build complex adpositions are allo-adpositions that map the same semantic content onto different phonological forms while containing Quichua syntactic features. This interpretation offers an explanation for those cases in which the complex part of the adpositions does not occur as relexified when a contextually inappropriate (that is, Quichua) variant is selected (1ob). As Muysken (1981) points out, there needs to be at least a partial overlap between semantic representations of source and target language entries for relexification to occur in the first place. ${ }^{18}$ This approach also accounts for the little syntactic interference (or structural priming) that occurs in production: In the speech production process, phonological encoding occurs at a later stage during formulation than syntactic encoding (Levelt, 1993; Myers-Scotton and Jake, 2012).

There is, however, one caveat with this interpretation: In every-day speech production, the relexified and not-relexified allo-adpositions should compete for selection (van Heuven et al., 1998; Sunderman and Kroll, 2006), especially if both Quichua and Spanish are simultaneously activated as well (e.g. Antoniou et al., 2011; Marian and Spivey, 2003; Shook and Marian, 2013; Goldrick et al., 2016). It is surprising that this does not lead to a larger incorporation of primed Quichua lexical items in Media Lengua translation responses, particularly since structural priming appears to have a small effect on the Media Lengua morphosyntactic frame. Perhaps, the lexical rule at work in the articulation of well-formed (that is, relexified) Media Lengua responses is powerful enough to overwrite these instances of lexical priming. On the basis of the striking

18 The current data set provides no evidence against overlapping semantic spaces when items are relexified, in line with Muysken's (1981) predictions. Additional research is required to target Media Lengua's semantic realm in more detail and to discuss the extent to which semantic representations of individual lexical items overlap or possibly undergo change during relexification. 
systematicity that characterizes Media Lengua as anything but a random mixture of Quichua and Spanish, it can be argued that it is not created from scratch every time it is spoken and that participants are aware of how this language operates. This argument is reinforced by the opinions some participants uttered during or after the experiment which confirm their metalinguistic awareness and their attitudes toward Media Lengua as a separate language. It is not inconceivable that some cases of structural priming might pass "below the radar" while lexical items are more easily caught as instances of less well-formed language use. Questions that remain to be explored in more detail are where the threshold lies between passing unnoticed and obviously ill-formed (but see Lipski, 2016, 2017) and which other linguistic categories or specific lexical items in Media Lengua resist priming.

6 Conclusion

The present study is one of only a few recent papers analyzing an extensive corpus of Media Lengua data. As demonstrated here, there is room for future research to address some of the idiosyncrasies uncovered in the present data set, including their bigger impacts on bilingual lexical representations, by studying contact languages like Media Lengua more systematically. As the present study shows, research on unique linguistic configurations such as Media Lengua can not only provide interesting results but may in fact serve to refine current linguistic theories.

\section{References}

Abney, Steven. 1987. The English Noun Phrase in its Sentential Aspect. Phd-Dissertation. MIT.

Antoniou, Mark, Catherine T. Best, Michael D. Tyler, and Christian Kroos. 2011. Interlanguage interference in voT production by L2-dominant bilinguals: Asymmetries in phonetic code-switching. Journal of Phonetics 39, 558-570. doi:10.1016/j. wocn.2011.03.001.

Asbury, Anna, Berit Gehrke, Henk van Riemsdijk, and Joost Zwarts. 2008. Introduction: Syntax and semantics of spatial P. In Anna Asbury, Jakub Dotlačil, Berit Gehrke and Rick Nouwen (eds.), Syntax and Semantics of Spatial P. Amsterdam/Philadelphia: John Benjamins, 1-32.

Baker, Mark C. 2003. Lexical Categories: Verbs, Nouns and Adjectives. Cambridge: Cambridge University Press. 
Bakker, Peter and Maarten Mous (eds.). 1994. Mixed Languages: ${ }_{15}$ Case Studies in Language Intertwining. Studies in Language and Language Use 13. Amsterdam: Institute for Functional Research into Language and Language Use.

Bakker, Peter and Pieter Muysken. 1994. Mixed languages and language intertwining. In Jacques Arends, Pieter Muysken and Norval Smith (eds.), Pidgins and Creoles: An Introduction. Amsterdam/Philadelphia: John Benjamins, 41-52.

Beckner, Clay and Joan Bybee. 2009. A usage-based account of constituency and reanalysis. Language Learning 59, 27-46. doi: 10.1111/j.1467-9922.2009.00534.x.

Bybee, Joan. 2010. Language, Usage and Cognition. Cambridge: Cambridge University Press.

Bock, J. Kathryn. 1986. Syntactic persistence in language production. Cognitive Psychology $18,355^{-387 .}$

Chan, Brian H-S. 2008. Code-switching, word order and the lexical/functional category distinction. Lingua 118, 777-809. doi:10.1016/j.lingua.2007.05.004.

Chomsky, Noam. 2015. The Minimalist Program. Cambridge (MA): MIT Press.

Cinque, Guglielmo. 2010. Mapping spatial PPs: An introduction. In Guglielmo Cinque and Luigi Rizzi (eds.), Mapping Spatial PPs: The Cartography of Syntactic Structures 6. Oxford/New York: Oxford University Press, 3-25.

Cole, Peter. 1982. Imbabura Quechua. Amsterdam: North-Holland Publishing.

Corver, Norbert. 2013. Lexical categories and (extended) projection. In Marcel den Dikken (ed.), The Cambridge Handbook of Generative Syntax. Cambridge: Cambridge University Press, 352-424.

Déchaine, Rose-Marie. 2005. Grammar at the borderline: A case study of P as a lexical category. Proceedings of the 24th West Coast Conference on Formal Linguistics, 1-18.

den Dikken, Marcel. 2010. On the functional structure of locative and directional PPs. In Guglielmo Cinque and Luigi Rizzi (eds.), Mapping Spatial PPs: The Cartography of Syntactic Structures 6. Oxford/New York: Oxford University Press, 74-126.

Dikker, Suzanne. 2008. Spanish prepositions in Media Lengua: redefining relexification. In Thomas Stolz, Dik Bakker and Rosa Salas Paloma (eds.), Hispanisation. The Impact of Spanish on the Lexicon and Grammar of the Indigenous Languages of Austronesia and the Americas (EALT 39). Berlin: Mouton de Gruyter, 131-157.

Escobar, Anna M. 200o. Contacto social y lingüístico: El español en contacto con el quechua en el Perú. Lima: Pontificia Universidad Católica del Perú.

Froud, Karen. 2001. Prepositions and the lexical/functional divide: Aphasic evidence. Lingua $111,1-28$.

Goldrick, Matthew, Michael T. Putnam, and Lara Schwarz. 2016. Coactivation in bilingual grammars: A computational account of code mixing. Bilingualism: Language and Cognition 19(5), 857-876. doi:10.1017/S1366728915000802.

Gómez Rendón, Jorge. 2008. Mestizaje lingüístico en los Andes: Génesis y estructura de una lengua mixta. Quito: Abya-Yala. 
Gries, Stefan Th. and Gerrit J. Kootstra. 2017. Structural priming within and across languages: a corpus-based perspective. Bilingualism, Language and Cognition 2o(2), 235-250. doi:10.1017/S1366728916001085.

Grimshaw, Jane. 200o. Locality and Extended Projection. In Peter Coopmans, Martin B.H. Everaert and Jane Grimshaw (eds.), Lexical Specification and Insertion. Amsterdam/Philadelphia:John Benjamins, 115-133. doi: 10.1075/cilt.197.

Hagège, Claude. 2010. Adpositions. Oxford/New York: Oxford University Press.

Hartsuiker, Robert J. and Casper Westenberg. 200o. Word order priming in written and spoken sentence production. Cognition 75, B27-B39. doi:10.1016/ Soo10-0277(99)00080-3.

Hartsuiker, Robert J., Martin J. Pickering, and Eline Veltkamp. 2004. Is Syntax Separate or Shared between Languages? Cross-Linguistic Syntactic Priming in SpanishEnglish Bilinguals. Psychological Science 15(6), 409-414.

van Heuven, Walter J. B., Ton Dijkstra, and Jonathan Grainger. 1998. Orthographic neighborhood effects in bilingual word recognition. Journal of Memory and Language $39,45^{8-483}$.

Jackendoff, Ray. 1977. X-Bar Syntax: A Study of Phrase Structure. Cambridge (MA): MIT Press.

Jackendoff, Ray. 1996. The architecture of the linguistic-spatial interface. In Paul Bloom, Mary A. Peterson, Lynn Nadel and Merrill F. Garrett (eds.), Language and Space, 1-30. Cambridge (MA)/London: MIT Press.

Koopman, Hilda. 2010. Prepositions, postpositions, circumpositions and particles: The structure of Dutch PPs. In Guglielmo Cinque and Luigi Rizzi (eds.), Mapping Spatial PPs: The Cartography of Syntactic Structures 6, 26-73. Oxford/New York: Oxford University Press.

Kootstra, Gerrit J., Janet G. van Hell, and Ton Dijkstra. 2010. Syntactic alignment and shared word order in code-switched sentence production: Evidence from bilingual monologue and dialogue. Journal of Memory and Language 63(2), 210-231. doi:10.1016/j.jml.2010.03.006.

Levelt, Willem J. M. 1993. Speaking. From Intention to Articulation. Cambridge (MA): Mit Press.

Lipski, John M. 2016. Language switching constraints: more than syntax? Data from Media Lengua. Bilingualism: Language and Cognition, 1-25. doi:10.1017/ S1366728916000468.

Lipski, John M. 2017. Ecuadoran Media Lengua: more than a "half"-language? International Journal of American Linguistics 83(2), 233-262.

Mackenzie, J. Lachlan. 2001. Adverbs and adpositions: The Cinderella categories of functional grammar. Revista Canaria de Estudios Ingleses 42, 119-135.

Marian, Viorica and Michael Spivey. 2003. Competing activation in bilingual language processing: Within- and between-language competition. Bilingualism: Language and Cognition 6(2), 97-115. doi:10.1017/S1366728903001068. 
Matras, Yaron. 2000. Mixed languages: A functional-communicative approach. Bilingualism: Language and Cognition 3(2), 79-99.

Matras, Yaron and Peter Bakker. 2003. The Mixed Language Debate: Theoretical and Empirical Advances. Berlin/New York: Mouton de Gruyter.

Meakins, Felicity and Jesse Stewart. forthcoming. Mixed languages. In Salikoko Mufwene and Anna M. Escobar (eds.), The Cambridge Handbook of Language Contact. Cambridge: Cambridge University Press.

Muysken, Pieter. 1981. Halfway between Quechua and Spanish: The case for relexification. In Arnold Highfield and Albert Valdman (eds.), Historicity and Variation in Creole Studies, 52-78. Ann Arbor: Karoma.

Muysken, Pieter. 1997. Media Lengua. In Sarah G. Thomason (ed.), Contact Languages: A Wider Perspective, 365-426. Amsterdam/Philadelphia: John Benjamins.

Muysken, Pieter. 2008. Functional Categories. Cambridge: Cambridge University Press. Muysken, Pieter. 2013. Language contact outcomes as the result of bilingual optimization strategies. Bilingualism: Language and Cognition 16(4), 709-730. doi:10.1017/ S1366728912000727.

Myers-Scotton, Carol. 1993. Duelling Languages: Grammatical Structure in Codeswitching. Oxford: Clarendon Press.

Myers-Scotton, Carol and Janice Jake. 2012. A universal model of code-switching and bilingual language processing and production. In Barbara E. Bullock and Almeida J. Toribio (eds.), The Cambridge Handbook of Linguistic Code-Switching, 336-357. Cambridge: Cambridge University Press.

O'Keefe, John. 1999. The Spatial Prepositions in English, Vector Grammar, and the Cognitive Map Theory. In Paul Bloom, Mary A. Peterson, Lynn Nadel and Merrill F. Garrett (eds.), Language and Space, 277-316. Cambridge (MA): MIT Press.

Pickering, Martin J. and Victor S. Ferreira. 2008. Structural priming: A critical review. Psychological Bulletin 134(3), 427-459. doi:10.1037/0033-2909.134.3.427.

$\mathrm{R}$ Core Team 2016. $R$ : A language and environment for statistical computing. Vienna: $\mathrm{R}$ Foundation for Statistical Computing. Available at http://www.R-project.org/ (accessed January 8, 2018).

Rauh, Gisa. 1991. Prepositional forms in the lexicon: problems and suggestions. In Gisa Rauh (ed.), Approaches to Prepositions, 169-223. Tübingen: Gunter Narr.

Sánchez, Liliana. 2012. Convergence in syntax/morphology mapping strategies: Evidence from Quechua-Spanish code mixing. Lingua 122, 511-528. doi:10.1016/j. lingua.2011.10.004.

Shappeck, Marco. 2011. Quichua-Spanish Language Contact in Salcedo, Ecuador: Revisiting Media Lengua Syncretic Language Practices. PhD Dissertation. University of Illinois: Urbana-Champaign.

Shook, Anthony and Viorica Marian. 2013. The bilingual language interaction network for comprehension of speech. Bilingualism 16(2), 304-324. doi:10.1017/ S1366728912000466. 
Stewart, Jesse. 2011. A Brief Descriptive Grammar of Pijal Media Lengua and an Acoustic Vowel Space Analysis of Pijal Media Lengua and Imbabura Quichua. Master's Thesis (University of Manitoba). Winnipeg.

Stewart, Jesse. 2013. Cuentos y tradiciones de Pijal: Relatos en Media Lengua. North Charleston: CreateSpace.

Stewart, Jesse. 2015. Intonation patterns in Pijal Media Lengua. Journal of Language Contact 8, 223-262. doi:10.1163/19552629-00802003.

Sunderman, Gretchen and Judith F. Kroll. 2006. First language activation during second language lexical processing: An investigation of lexical form, meaning and grammatical class. SSLA 28, 387-422. doi:10.1017/So272263106060177.

Terzi, Arhonto. 2008. Locative Prepositions as Modifiers of an Unpronounced Noun. Proceedings of the 26th West Coast Conference on Formal Linguistics, 471-479.

Zwarts, Joost. 1997. Lexical and functional properties of prepositions. In Dagmar Haumann and Stefan J. Schierholz (eds.), Lexikalische und grammatische Eigenschaften präpositionaler Elemente, 1-18. Tübingen: Niemeyer.

Zwarts, Joost. and Yoad Winter. 200o. Vector space semantics: A modeltheoretic analysis of locative prepositions. Journal of Logic, Language and Information 9(2), 171-213.

Zwarts, Joost. 2003. Vectors across spatial domains: From place to size, orientation, shape and part. In Emile van der Zee and Jon Slack (eds.), Representing Direction in Language and Space, 39-68. Oxford/New York: Oxford University Press. doi:10.1093/ acprof:oso/9780199260195.003.0003. 


\section{Appendix}

\section{$1 \quad$ Complete List of Stimuli}

\subsection{Spanish Translation}

La mujer pone la madera en una bolsa para llevarla al mercado.

El árbol que está frente a mi casa es muy bonito.

En el mercado, las mujeres sacan papas de una bolsa.

Voy a la casa de mi abuelo para comer arroz.

Me voy de la casa de mi abuela porque es tarde.

La señora abre la puerta para el niño en la tarde.

El padre cierra la puerta detrás del niño en la tarde.

La abuela pone flores en la mesa para la fiesta.

El hombre lleva un sombrero en la cabeza.

La madre cocina arroz en la casa a las 11 de la mañana.

El niño sale por la puerta después de comer.

La gallina salió por la ventana. Nunca va a volver a la casa.

El niño iba hacia la casa de su abuela cuando lo secuestraron.

La niña duerme en la casa. Tiene una cama grande.

El hombre pone la jícama en la bolsa para llevarla a la casa.

La mujer cubre las semillas con la tierra.

La mujer corta la cebolla con el cuchillo.

Para cocinar la jícama, la mujer la pela, la corta y la pone en una olla grande.

El hombre y la mujer no se volvieron a ver hasta el próximo día.

El hombre solo llegó hasta Quito ese día. No alcanzó a llegar a Guayaquil.

Los hombres y el niño caminaron por el bosque.

Después de cocinar, la mujer saca la comida del horno.

El hombre volverá del mercado de Otavalo a las 5 de la tarde.

La mujer y el hombre hablan en la casa a las 3 de la tarde.

El niño viene de la casa de la abuela con una bolsa de jícamas.

Para llegar a Guayaquil, el hombre tiene que pasar por Quito.

La abuela anda por el jardín buscando las patatas.

La vaca camina detrás del hombre en la calle.

Yo voy a caminar para la casa de Maria a las 3 de la tarde.

Hay una carretera desde Quito hasta Guayaquil.

Warmica shuc caspita bolsapi churan jatun pampaman apangapag. Chay yura ñuca wasi ñawpagpica sumagmi can. 
Jatun pampapi, warmicunaca papacunata shuc costalmanta yugchin.

Ñuca jatun taitapag wasiman rini, arrozta micungapag.

Jatun mamapag wasimanta rini, ña chishicagpi.

Shuc mamaca punguta pascan chishipi chay wawapag.

Taitaca punguta wichcan wawapag washapi chishipi.

Yaya mamaca sisacunata patajawapi churan raymipa.

Jarica muchicuta apan paypag umapi.

Mamaca arrozta yanun wasipi, chungashuc tutamantapi.

Wawaca punguta yugshin micushcaquipa.

Atalpaca ventanamanta yugshirca. Chaymantaca mana wasimanca tigrangachu.

Wawca yaya mamapag wasiman rirca. Chaypimi payta shuwacuna japirca.

Warmi wawaca wasipi puñun. Payca jatun cawituta charin.

Chay jarica shuc costalpi jicamata churan wasiman apangapag.

Warmica muyucunata alpawan quilpan.

Warmica cebollata cuchun cuchillowan.

Jicamata yanungapagca warmica carata yugchin, cuchunpash, chaimanta jatun mangapi churan.

Jarica warmiwan mana ricurircachu chay mincha punchacaman.

Jarica Quitocamanya chayarca chay punchaca. Mana chayayurcachu Guayaquilmanca.

Jaricuna wawacunawan bosqueta rircacuna.

Yanushcaquipaca, warmica shuc hornomanta micunata yugchirca.

Chay jarica pichcapacha chishipimi Otavalo jatun pampamanta tigramunga.

Warmica hariwan rimarin wasipi, quimsa pacha chishipi rimarin.

Wawaca jatun mamapag wasimantami shuc costal jicamawan shamun.

Guayalquilman chayangapag, jarica Quitotami yalina can.

Jatun mamaca sisa pambaucuta papata mashcashpa rin.

Warmi wagraca haripag washata catin chay ñantaca.

Nucaca Maríapag wasiman quimsa pacha chishipi rigrini.

Quitomanta Guayaquilman shuc ñanmi tian.

2

\section{Media Lengua Example Response}

Data provided by Dolores (name changed), a student at Topo High School in the third (last) year of the bachillerato (secondary education). She was born in Casco Valenzuela just as her parents and indicates Media Lengua as her first and preferred language. She rates herself as very proficient in Media Lengua (5) and Spanish (5) and good in Quichua (4) on a scale from 1 (little proficiency) to 5 (very proficient). She reports learning both Media Lengua and Quichua at 
home, but Spanish at school and speaks mostly Media Lengua with her siblings while opting for Spanish to talk to her friends. Her parents use mostly Media Lengua; her grandparents mostly Quichua. She never speaks Media Lengua or Quichua when she visits bigger cities like Otavalo or Quito. Her response to the task as well as her reported linguistic background are good examples of the type of response most participants gave.

The transcription follows Spanish orthography (written "j" pronounced as $[\mathrm{h}])$. Slashes indicate hesitations and truncated forms. Phonetic idiosyncracies such as raising of mid vowels or consonant voicing (e.g. /p/ as [b] and $/ \mathrm{s} /$ as $[\mathrm{z}]$ ), though frequently found in responses, are not orthographically represented here.

Video 1: A man is calling a little boy.
(1) ese...ese taita-ca grita-ju-n wawa-ta
DEM...DEM guy-TOP shout-PROG-3SG child-ACC
'That man is calling the child.'

Video 2: A woman is preparing a traditional dish using quinoa, cheese, egg and onion.
(2a) ese mama-ca queso-ta rasga-ju-n
DEM woman-TOP cheese-ACC grate-PROG-3SG
'That woman is grating cheese.'

(2b) ese comida-ca quinoa comida-mi ca-n

DEM food-Top quinoa food-Foc be-3sG

'That food is quinoa food.'
(2c) cebolla-ta pica-ju-n cocina-ngapag
onion-ACC cut-PROG-3SG cook-in.order.to

'[The woman] is cutting the onion, in order to cook.'
(2d) quinoa/quinoa chapu-sha-ta queso-wan chapu-ju-n quinoa/quinoa mix-PTCP-ACC cheese-with mix-PROG-3sG '[She] is mixing the mixed quinoa with cheese.'

(2e) huevo-ta pone-ju-n

egg-ACC put-PROG-3sG

'[She] is adding an egg.' 
Video 3: A group of men is dancing the traditional Inti Raimi dance (during the festival of the sun) and drinking chicha, an alcoholic drink made from formented corn.

(3) ese wamra-cuna-ca baila-na-ju-n chicha-ta toma-shpa-wan DEM male-PL-TOP dance-RECP-PROG-3PL chicha-ACC drink-SUB-with 'These men are dancing while drinking chicha.'

Video 4: A woman is seen in the kitchen, where she is preparing a traditional dish with sweet potato purée and lemon juice.

(4a) ese mama-ca cocina-pi olla-ta para-chi-ju-n cocina-ngapag DEM woman-TOP kitchen-in pot-ACC stand-CAUS-PROG-3SG cook-in.order.to 'That woman is putting a pot [on the stove] in the kitchen for cooking.

(4b) ese mama-ca limon-ta parti-ju-n jugo-ta hace-ngapag DEM woman-TOP lemon-ACC cut.in.half-PROG-3SG juice-ACC make-in.order.to 'That woman is cutting a lemon in half in order to make juice.'

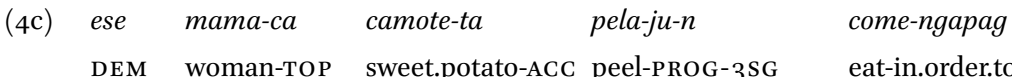

'That woman is peeling the sweet potato, in order to eat [it].'

(4d) ese mama-ca camote-ta apiya-chi-shpa cocina-ju-n DEM woman-TOP camote-ACC smooth-CAUS-SUB cook-PROG-3SG

'That woman is cooking the camote, having turned it into purée.'

(4e) ese mama-ca come-gri-ju-n

DEM woman-TOP eat-FUT-PROG-3SG

'That woman will be eating.'

Video 5 not included.

Video 6: A man is waiting outside of a house. He then enters the house and begins talking to a woman that is placing fire wood in an oven.

(6a) ese taita-ca chapa-ju-n

DEM guy-TOP see-PROG-3SG

'That man is watching.' 
(6b) casa-man entra-gri-ju-n

house-into enter-FUT-PROG-3SG

'[He] will be entering the house.'

(6c) ese mama-ca llanta-ta mete-ju-n horno-man cocina-ngapag DEM woman-TOP wood-ACC put-PROG-3SG oven-into cook-in.order.to 'That woman is putting the fire wood into the oven in order to cook.'

(6d) ese taita-wan parla-ri-ju-n

DEM guy-with speak-RECP-PROG-3SG

'[She] is speaking with that man.'

Video 7 not included.

Video 8: A teenage girl is getting up from the ground and walking towards a house. She knocks on the door and an older woman opens. They talk briefly and the girl is sent away. The older woman closes the door and the girl sits back down outside, covering herself with a blanket.

(8a) chay mama-cal ese mama-ca jatari/levanta-ju-n

DEM woman-TOP DEM woman-TOP get.up-PROG-3SG

'That woman...that woman is get-...is getting up.'

(8b) puerta-ta golpea-ju-n

door-ACC knock-PROG-3SG

'[She] is knocking on the door.'

(8c) ese mama-ca chapa-ju-n wawa-ta

DEM woman-TOP see-PROG-3Sg child-ACC

'That woman is looking at the child.'

(8d) ese wawa-ca ve-ju-n ese mama-ta

DEM child-TOP see-PROG-3SG DEM woman-ACC

'That child is looking at that woman.'

(8e) ese mama/ ese wawa-ca anda-ju-n

DEM woman DEM child-TOP walk-PROG-3SG

'That woman...that child is walking.'

(8f) senta-ri-ju-n, dormi-gri-ju-n ese wawa-ca afuera-pi sit-REFL-PROG-3SG sleep-FUT-PROG-3SG DEM child-TOP outside-in '[The child] is sitting down, that child will be sleeping outside.' 
Video 9 not included.

Video 10: A woman is lighting a match and starting a fire to cook potatoes.

(10a) ese mama-ca tulpa-ta $\quad$ japichi-ju-n
DEM woman-TOP stove-ACC
'Thake.fire-PROG.3SG
Thoman is lighting the stove.'
(1ob) jatun olla-pi cocina-ju-n
big pot-in cook-PROG-3SG
'[She] is cooking in a big pot.'
(10c) papa-ta cocina-ju-n
potato-ACC cook-PROG-3SG
'[She] is cooking potatoes.'
(1od) papa-ta vishi-ju-n come-ngapag
potato-ACC serve-PROG-3SG eat-in.order.to
'[She] is serving the potatoes [with a big spoon], in order to eat.'

Video 11-16 not included.

Video 17: A woman is seen crying. Then a man arrives, they hug each other and he takes her inside a house, putting her to sleep on a mat. Outside, a group of men is dancing the Inti Raimi dance.
(17a) ese mama-ca llora-ju-n
DEM woman-TOP cry-PROG-3SG
'That woman is crying.'

(17b) ese taita abraza-ju-n

DEM guy hug-PROG-3SG

'[She] is hugging that man.'

'That man is hugging [her].'
$\left({ }^{17} \mathrm{c}\right)$ ese taita-cuna-ca baila-na-ju-n $y$
DEM guy-PL-TOP dance-RECP-PROG-3SG and
'Those men are dancing and...'



(17d) ese mama-ta ucu/adentro-man lleva-na-ju-n
DEM woman-ACC inside-toward bring-RECP-PROG-3SG
'...they are taking that woman inside.'
(17e) ese mama-ta dormi-chi-ju-n ese taita
DEM woman-ACC sleep-CAUS-PROG-3SG DEM guy

'That man is making that woman sleep [putting her to sleep].'

(17f) ese mama dormi-ju-n

DEM woman sleep-PROG-3SG

'That woman is sleeping.'

Video 18-21 not included.

Video 22: A group of men is walking into a forest with a little boy. On their way, the pass somebody who is peeling potatoes. Then, one man ties the boy's hands to a tree and the group leaves him there.

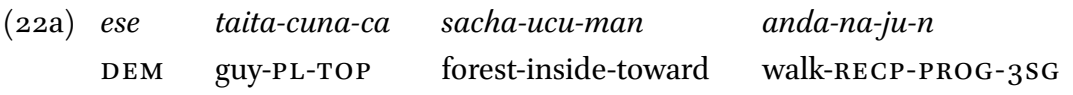

'Those men are walking into the forest.'

(22b) ese wawa-ca camina-ju-n sacha-ucu-ta

DEM child-TOP walk-PROG-3SG forest-inside-through

'That child is walking through the forest.'

(22c) ese wawa-ca papa-ta pela-ju-n

DEM child-TOP potato-ACC peal-PROG-3SG

'That child is pealing potatoes.'

(22d) ese taita-ca wawa-ta senta-chi-shpa deja-rca-ø

DEM guy-ToP child-ACC sit-CAUSE-Sub leave-PST-3SG

'That man, having made the child sit down, left it [there].'

(22e) soga-ta amarra-ju-n

rope-ACC tie.up-PROG-3sG

' $[\mathrm{He}]$ is tying up the rope.' 